\title{
The Role of Organic and Bio-Fertilizers in the Validity of Phosphate Fertilizers and their Effect on the Faba Bean Grown in Clay Soil El-Ghamry, A. M. ${ }^{1}$; E. M. El-Naggar ${ }^{2}$ and H. Hassan ${ }^{2}$ \\ ${ }^{1}$ Soils Dept., Faculty of Agriculture, Mansoura University, Egypt \\ ${ }^{2}$ Agric. Res., Egyptian Fertilizers Development Center, Delta Fertilizer Company
}

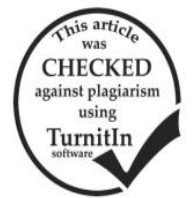

\section{ABSTRACT}

A pot experiment was carried out in 2015/2016 to study the role of organic and bio-fertilizers in the validity of mineral phosphate fertilizers and their effect on the beans grown in clay soil. The obtained results could be summarized as follows: There was a significant increase in the mean values of plant height, seed yield, the weight of 100 seeds and crude protein due to phosphorus fertilizers solely or in combination with bio and organic fertilization compared with the control. In addition, the mean values of $\mathrm{N}, \mathrm{P}, \mathrm{K}, \mathrm{Fe}, \mathrm{Zn}$ and $\mathrm{Mn}$ concentrations in the straw and seeds of faba bean plant after harvest stage were significantly increased. Using organic and biofertilizers coupled with phosphate rock or super phosphate increase the availability of plant nutrients and its productivity and reduces the soil pollution resulted from mineral fertilizers.

Keywords: organic fertilizers, bio fertilizers, phosphate fertilizers, been, clay soil .

\section{INTRODUCTION}

Faba bean (Vicia faba L.) is considered one of the most important green leguminous plants that grown in the winter season at different types of soils in Egypt. In addition, it is considered as one of the most important sources of protein, so it is very necessary to get a clean product of faba bean., many attempts took place in the recent years in order to avoid the harmful effects of chemical fertilizers and replace it with bio-organic farming fertilizers are the recent trend, newly introduced in the agricultural practice of getting clean products. Application of these systems in the agriculture regimes became inevitable to put an end to the unwise doses of harmful chemical fertilizers that are used for increasing crop productivity. Soil application of organic and biofertilizers is the most common method used in bioorganic farming systems. (Nassib et al., 1991; Duc, 1997 and El-Ghamry et al., 2009).

Phosphorus (P) is one of the most important nutrient element limiting agricultural production, and nonrenewable natural resource. Phosphorus is the second major fertilizer after nitrogen and it is added to the soil mainly as superphosphate. It has an important role in the physiology of plants as it is taking part in the structure of genetic and energy compounds. Phosphorus is an essential component of ATP, which is called "energy unit" in plants, so it is very important for the general health of plants. Some specific growth factors that have been associated with phosphorus have stimulated root development, increased stalk moreover, stem strength, improved flower formation, and seed production increased nitrogen $\mathrm{N}$-fixing capacity of legumes, improvements in crop quality, and increased resistance to diseases of plants. Phosphorus is an essential component of DNA, the genetic "memory unit" of all living things. It is also a component of RNA, the compound that reads the DNA genetic code to build proteins and other compounds essential for plant structure and seed yield. (Johnston, 2001; Brady, 1990; Goldstein et al., 1998; El-Ghamry et al., 2009 and Glæsner et al., 2016).

Phosphate rock (PR) is extracted from geologic deposits. Apatite, a calcium phosphate mineral, is the primary component of PR. It is primarily extracted from sedimentary marine deposits. Adding phosphate rock to soil, it slowly dissolves, but it is too slow to support healthy plant growth in some soils. P fertilizers (MAP, DAP, SSP, and TSP are made from RP that is formed from ancient marine sediments (Van Kauwenbergh, 2010). Direct application of RP could reduce pollution and the costs of chemical treatment. RP becomes as effective as superphosphate only after 4 years of annual direct application (Ghani et al., 1994) they also, studied the ability of the roots of the plant of solubilizing various sources of RP and showed the factors that may facilitate their activities in solubilizing rock phosphate by adding organic matter or sulfur on (Vicia faba). The behavior of rock phosphates in the soil indicated slight solubilization in the alluvial soil. (Elgala and Amberger, 2017).

Bio-fertilizers generates plant nutrients such as nitrogen and phosphorous through their activities in the soil or rhizosphere and makes them available to plants in a gradual manner. Phosphate solubilizing bacteria can be used to turn soil phosphorus to available forms, which can be absorbed by plants. It can be used for either seed treatment or soil application. (Rai, 2006 and Haile et al., 2014). RP application is not economically appropriate in the soil conditions such as high $\mathrm{P}$ absorption capacity, $\mathrm{pH}$ high, low contents of organic matter, low cation exchange and low activity of biological activity. Therefore, it was very necessary to treat rock or super phosphate by biological techniques for improving its agronomic impact (Rodriguez and Fraga 1999; Whitelaw 2000; Vassilev et al., 2002 and Baddour et al., 2004)

Muraleedharan et al., (2010) classified the biofertilizers to $\mathrm{N}$-fixing biofertilizers, phosphorous solubilizing biofertilizers (PSB), and phosphate mobilizing biofertilizer (mycorrhizae). A lot of $\mathrm{P}$ in soils is fixed as well as soil microorganisms have the ability to convert insoluble phosphorus into soluble, it is named (PSM). These organisms supply plants with soluble $\mathrm{P}$, encourage the plant's growth by many other mechanisms, enhanced the nutrient uptake (Abou ElYazeid and Abou-Aly, 2011 and Khan et al., 2014).

El-Ghandour et al., (2005) studied the effect of inoculation of rhizobia on the growth, $\mathrm{P}$ and $\mathrm{N}$ uptake by (Vicia faba L.) in sandy soil, treated with super or RP. The earthen pots treated with half of the recommended dose of $\mathrm{P}$ as either SSP or RP. It showed that fungal infection and rhizobia inoculation improved dry matter yield. The rates of increase in the dry matter were $(34,26$ and $57 \%)$ for SSP, however, it as $(56,47$ 
and $89 \%$ ) in RP inoculated with Rhizobium. Inoculation also improves $\mathrm{P}$ and $\mathrm{N}$ uptake.

Adding organic fertilizers such as compost, and chicken manure to soils is a current environmental and agricultural practice for human health and have a direct effect on soil organic matter content, improve soil fertility. It has an important role in solubilizing of $\mathrm{P}$ and enhancing its absorption as well as enhancing crop productivity (Wong and Swift, 2003; Aggelides and Londra, 2000; Chaturvedi et al., 2008 and Escobar and Hue, 2008). Composting is used to convert agro-wastes to eco-friendly fertilizers. RP is best solubilized when introduced into decaying lignocellulose, and only biologically active organic matter enhances P availability in soil (Iyamuremye and Dick 1996). Adding agro-wastes followed by composting with RP increased the availability of $\mathrm{P}$ in plants (Singh and Amberger 1991, 1995). Seven organic acids were found in the compost material-oxaloacetic, citric, fumaric, succinic, tartaric, malic, and glycolic, which in turn affected the P solubilizing efficiency. Biswas and Narayanasamy, (2002) reported that the addition of RP during composting enhanced $\mathrm{P}$ mobilization of crop residue. To increase the content of organic acids and the RP solubilization by enriching the compost material with nitrogen and molasses, they noted that (24-25\%) of the total added RP was solubilized after 120 days (Singh and Amberger, 1998). The organic farming system depends on incorporating organic manures (e.g. farmyard manure, compost or green manure) into the rhizosphere; this requires huge amounts of organic matter to achieve a significant effect (Mosa, 2012). It is very important to manufacture eco-friendly organic manure source enriched with high nutrients content to compete with mineral sources, (El-Ghamry et al., 2016). Crop productivity was enhanced, significant improvement in the quality of enriched manure (i.e. $\mathrm{C} / \mathrm{N}$ ratio and nutrient content) and significant increase in $\mathrm{N}, \mathrm{P}$ and $\mathrm{K}$ concentrations by modern enriched organic manures as compared with absolute organic manures (El-Ghamry et al., 2016) phosphate rock (PR) dissolution are affected by organic matter.

The aim of this research is to investigate the role of organic fertilizer and bio-fertilizers in the availability of phosphorus from different sources of mineral phosphate fertilizers and their effect on the faba bean plant cultivated in clay soil.

\section{MATERIALS AND METHODS}

\section{Experimental design:}

A pot experiment was carried out in the winter season of 2015/2016 under greenhouse in the Egyptian Fertilizer Development Center, Delta Company for Fertilizers and Chemical Industries, Talkha, Dakahlia Governorate to study the role of organic and biofertilizers in the validity of mineral phosphate fertilizers (rock and super phosphate) and their effect on the faba bean (Vicia faba L.), Giza 76 yield grown in a clay soil. The soil of the experimental farm was clayey in texture, some chemical and mechanical analysis as described by (Chapman and Prat, 1962) and Jackson, (1967) are shown in Table 1.
Table 1. Some physical and chemical properties of the experimental soil before planting

\begin{tabular}{|c|c|c|c|}
\hline \multicolumn{3}{|c|}{ Soil characteristics } & Values \\
\hline \multirow{5}{*}{\multicolumn{2}{|c|}{ Mechanical analysis $(\%)$}} & se sand & 1.70 \\
\hline & & Sand & 19.8 \\
\hline & & iilt & 28.4 \\
\hline & & lay & 50.1 \\
\hline & & exture & Clay \\
\hline & 35.0 \\
\hline \multicolumn{3}{|c|}{$\mathrm{CaCO}_{3}\left(\mathrm{~g} \mathrm{~kg}^{-1}\right)$} & 40.0 \\
\hline \multicolumn{3}{|c|}{$\mathrm{OM}\left(\mathrm{g} \mathrm{kg}^{-1}\right)$} & 11.0 \\
\hline & 7.80 \\
\hline \multicolumn{3}{|c|}{$\mathrm{EC}\left(\mathrm{dSm}^{-1}\right)$} & 1.19 \\
\hline \multirow{8}{*}{ Soluble ions } & \multirow{4}{*}{$\begin{array}{l}\text { Soluble } \\
\text { cations } \\
\left(\text { mmole } \mathrm{L}^{-1}\right)\end{array}$} & $\mathrm{Ca}^{++}$ & 3.80 \\
\hline & & $\mathrm{Mg}^{++}$ & 1.00 \\
\hline & & $\mathrm{Na}^{+}$ & 6.10 \\
\hline & & $\mathrm{K}^{+}$ & 1.00 \\
\hline & \multirow{4}{*}{$\begin{array}{l}\text { Soluble } \\
\text { anions } \\
\left(\text { mmole } \mathrm{L}^{-1}\right)\end{array}$} & $\mathrm{CO}_{3}^{--}$ & 0.00 \\
\hline & & $\mathrm{HCO}_{3}^{-}$ & 0.90 \\
\hline & & $\mathrm{Cl}^{-}$ & 5.40 \\
\hline & & $\mathrm{SO}_{4}^{--}$ & 5.60 \\
\hline \multirow{2}{*}{\multicolumn{3}{|c|}{$\begin{array}{l}\text { Available- P (mg kg-1 } \text { soil) } \\
\text { Available- N (mg kg} \\
\text { ( }{ }^{-1} \text { soil) }\end{array}$}} & 4.73 \\
\hline & & & 50.0 \\
\hline
\end{tabular}

The chemical properties of the compost, rock and super phosphate are shown in Table 2.

Table 2. Chemical properties of the Super phosphate, rock phosphate and compost.

\begin{tabular}{lccc}
\hline Characteristics & $\begin{array}{c}\text { Super } \\
\text { phosphate }\end{array}$ & $\begin{array}{c}\text { Rock } \\
\text { phosphate }\end{array}$ & Compost \\
\hline $\mathrm{pH}$ & 3.2 & 7.8 & 5.2 \\
$\mathrm{EC}\left(\mathrm{dSm}^{-1}\right)$ & 4.5 & 3.0 & 6.0 \\
\hline Total macro-nutrients & $\%$ & $\%$ & $\mathrm{mg} \mathrm{kg}^{-1}$ \\
$\mathrm{~N}$ & $\mathrm{Nil}$ & $\mathrm{Nil}$ & 2380 \\
$\mathrm{P}$ & 14.8 & 28.0 & 2450 \\
$\mathrm{~K}$ & $\mathrm{Nil}$ & 0.04 & 1960 \\
\hline
\end{tabular}

Soil analysis:

The mechanical analysis was determined according to the international pipette method as described by Piper, (1950). Saturation percentage (SP) and field capacity (FC) of the soil were determined using the method described by Richards, (1954). Total carbonates were determined as calcium carbonate using Collins calcimeter (Piper, 1950). Soil pH was determined in soil paste using a Gallen Kamp pH-meter (Jackson, 1967). Total soluble salts were determined by measuring the electrical conductivity (EC) using the electrical conductivity meter (EC meter Model TD Scan 3 ) in saturation extract of soil in $\mathrm{dSm}^{-1}$ [United States Salinity Laboratory Staff] (Richards, 1954). The amounts of soluble ions mmole $\mathrm{L}^{-1}$ in the soil were determined in saturation extract, according to (Hesse, 1971) as follows: (Soluble calcium and magnesium $\left(\mathrm{Ca}^{++}, \mathrm{Mg}^{++}\right)$were determined by the versenate method Soluble sodium and potassium $\left(\mathrm{Na}^{+}, \mathrm{K}^{+}\right)$were determined by using the flame photometer (Model Jenway PFP7). Carbonate and bicarbonate $\left(\mathrm{CO}_{3}^{--}\right.$, $\mathrm{HCO}_{3}{ }^{-}$) were determined by titration with a standardized $\mathrm{H}_{2} \mathrm{SO}_{4}$ solution. Chloride $\left(\mathrm{Cl}^{-}\right)$was titrated with silver nitrate. Sulphate $\left(\mathrm{SO}_{4}^{--}\right)$was determined by the difference between som of cations $\left(\mathrm{Ca}^{++}, \mathrm{Mg}^{++}, \mathrm{Na}^{+}\right.$, 
$\left.\mathrm{K}^{+}\right)$and anions $\left(\mathrm{CO}_{3}^{--}, \mathrm{HCO}_{3}^{-}, \mathrm{Cl}^{-}\right)$.Available $\mathrm{N}$ was extracted by $\mathrm{KCl} 2 \mathrm{~N}$ extract ant and determined by steam- distillation procedure using $\mathrm{MgO}$ - Devarda ally according to the methods described by Black, et al., (1965). Available phosphorus in the soil was extracted with $0.5 \mathrm{M} \mathrm{NaHCO}_{3}{ }^{-}$solution ( $\mathrm{pH} 8.5$ ) and determined using spectrophotometer after treating with ammonium molybdate and stannous chloride at a wavelength of 660 $\mathrm{nm}$ (Olsen and Sommers, 1982).Available K was extracted using $1 \mathrm{~N}$ ammonium acetate at $\mathrm{pH} 7.0$ and was determined by flam photometerically according to Black, et al., (1965).

Plant analysis:

To determine the concentrations of nutrients in plant tissues, $0.2 \mathrm{gm}$ from each ground oven-dried samples were digested using $5 \mathrm{ml}$ from the mixture of sulphuric $\left(\mathrm{H}_{2} \mathrm{SO}_{4}\right)$ and perchloric $\left(\mathrm{HClO}_{4}\right)$ acids $(1: 3)$ as described by Peterburgski, (1968). Nitrogen was determined by the micro-Kjeldahl method as explained by Hesse, (1971). Phosphorus was determined colorimetrically at wavelength $660 \mathrm{~nm}$ using the spectrophotometer (Spekol) as described by Jackson, (1967). Potassium was determined by using the Gallen Kamp flame photometer as mentioned by Jackson, (1967). Crude protein percentage was determined in the dry seeds by determination of $\mathrm{N}$ percentage and was multiplied in 6.25 according to AOAC, (1970). Utilization rate formula of applied $\mathrm{P}$ fertilizer was calculated according to Finck, (1982). Total micronutrients $(\mathrm{Fe}, \mathrm{Zn}$ and $\mathrm{Mn})$ contents $\left(\mathrm{mg} \mathrm{kg}^{-1}\right)$ were determined in the digested plant materials by using an atomic absorption spectrophotometer; model of VARIAN specter AA.20 according to Mathieu and Pieltain, (2003). Total chlorophyll in the leaves was estimates by using analytical apparatus; chlorophyll meter (model SPAD-502) Minolta Camera Co. ltd, japan.

The experimental design was one-way random design with three replicates, and the following phosphorus treatments were applied:

1. Control treatment (untreated soil).

2. SSP (Single Super Phosphate).

3. RP (Rock Phosphate).

4. SSP + O.M (Organic Manure - compost).

5. $\mathrm{RP}+\mathrm{O} . \mathrm{M}$.

6. $\mathrm{SSP}+\mathrm{Bio}$ (Biofertilizers - mycorrhiza)

7. $\mathrm{RP}+\mathrm{Bio}$.

On $10^{\text {th }}$ 0ctobar 2015, Super phosphate has been added to the treatments $(2,4,6)$ before two weeks from Cultivation. Rate added $207 \mathrm{~kg}$ (SSP) per fidden, 2.45 per gm SSP per pot. In addition, Compost has been added to the treatments $(4,5)$, at rate of 5 tin for fidden, 60 gm per pot. On $28^{\text {th }}$ 0ctobar, the seeds, were divided into seven parts and inoculation with Okadin ;( Rhizobium sp.).In addition, it has been added RP at the rate of $100 \mathrm{~kg}$ per fidden, 1.2 gm per pot to the treatments $(3,5,7)$ also, it has been added a solvent bacteria Phosphate mycorrhiza; (Glomus macrocarpium) to the treatment $(6,7)$. After 35 days (Vegetative growth stage) and 54 days (flowering stage) from the sowing of faba bean seeds respectively, two plants were randomly taken from each treatment and immediately the plant growth parameters were measured.
After 135 days (at harvest), two plants were randomly taken from each pot to determine some characters.

Statistical Analysis:

All data were subjected to proper statistical analysis of variance (ANOVA) of randomized complete block design by Gomez and Gomez (1984). Mean values of treatments were differentiated by using LSD according to procedure outlined by (Steel and Torrie 1980).

\section{RESULTS AND DISCUSSION}

\section{Vegetative growth}

Data in Table (3) illustrated the effect of sources of phosphorus fertilizers with and without Bio fertilizers (mycorrhiza) and organic fertilizers (compost) on plant height $(\mathrm{cm})$ at flowering stage and after harvest stage of faba bean .Data presented reveal a significant increase in the mean values of all growth parameters studied due to bio and organic fertilizers. It is noticed that the addition of (SSP+ Bio) showed the highest increase in plant height $(43.6 \mathrm{~cm})$ at an increased rate $(22.47 \%)$. In addition, this addition showed the highest increase in plant height after harvest $(101.42 \mathrm{~cm})$ at an increased rate $(19.0 \%)$ compared to control.

Table 3. Effect of sources of phosphorus fertilizers with and without Bio and organic fertilizers on plant height $(\mathrm{cm})$ at flowering stage and at harvest.

\begin{tabular}{lcc}
\hline \multirow{2}{*}{ Treatment } & \multicolumn{2}{c}{ Plant height (cm) } \\
\cline { 2 - 3 } & Flowering stage & After harvest \\
\hline Control & 35.60 & 85.20 \\
SSP & 39.13 & 97.30 \\
RP & 37.93 & 94.46 \\
SSP + OM & 41.44 & 98.95 \\
RP + OM & 41.00 & 94.50 \\
SSP + Bio & 43.60 & 101.42 \\
RP + Bio & 42.20 & 93.00 \\
f- test & $*$ & $*$ \\
LSD \% & 4.150 & 7.918 \\
\hline
\end{tabular}

Control $=$ untreated soil, SSP $=$ Single Super Phosphate, RP $=$ Rock Phosphate, $\mathrm{O} . \mathrm{M}=$ Organic Manure (compost), and Bio = Biofertilizers (mycorrhiza).

These results could be enhanced by those obtained by Abdel-Haleem, (1994) and Abdalla, (2002) could enhance these results they showed the impact of mineral $\mathrm{P}$ on the growth and productivity of Vicia faba by using superphosphate at $150-200 \mathrm{~kg}$ SSP fidden ${ }^{-1}$ increased plant growth characters (plant height, number of branches).

\section{Yield and yield component of faba bean:}

Data presented in Table (4) indicated that the effect of sources of phosphorus fertilizers with and without bio and organic fertilizers on straw weights (fresh and dry weight, $g$ plant ${ }^{-1}$ ) in clay soil at harvest stage and on seed weights after harvest. The average values were high significantly increased due to biofertilizers and organic fertilization. The highest values (678.3 and $78.79 \mathrm{~g} \mathrm{plant}^{-1}$ ) of fresh weight and dry weight at harvest stage were recorded under the addition treatment of (SSP + Bio) giving an increased rate of (37.39 and $27.45 \%)$ respectively compared to control, treatment. It could be revealed that SSP with bio addition at all treatment gives higher fresh and dry weight, $g$ plant ${ }^{-1}$ than rock phosphate with bio and organic fertilizers While, seeds weight after 
the harvest was significantly increased as affected by addition treatments. Highest values (157.63 and $64.80 \mathrm{~g}$ plant $^{-1}$ ) of fresh and dry weight of seeds were obtained when plants treated with $(\mathrm{SSP}+\mathrm{OM})$ with an increase of (25.8 and $20.0 \%$ ), respectively compared to control, treatment.

Table 4. Effect of sources of phosphorus fertilizers with and without bio and organic fertilizers on straw and seed weights in faba bean.

\begin{tabular}{|c|c|c|c|c|}
\hline \multirow[b]{2}{*}{ Treatment } & \multicolumn{2}{|c|}{ Straw weight } & \multicolumn{2}{|c|}{ Seed weight } \\
\hline & $\begin{array}{c}\text { Fresh } \\
\text { weight } \\
\left(\text { g plant }^{-1}\right)\end{array}$ & $\begin{array}{c}\text { Dry } \\
\text { weight } \\
\left(\text { g plant }^{-1}\right)\end{array}$ & $\begin{array}{c}\text { Fresh } \\
\text { weight } \\
\left(\text { g plant }^{-1}\right)\end{array}$ & $\begin{array}{c}\text { Dry } \\
\text { weight } \\
\left(\text { g plant }^{-1}\right)\end{array}$ \\
\hline Control & 493.72 & 61.75 & 125.31 & 54.00 \\
\hline SSP & 663.76 & 73.46 & 154.10 & 61.71 \\
\hline $\mathrm{RP}$ & 592.16 & 66.36 & 138.61 & 59.11 \\
\hline $\mathrm{SSP}+\mathrm{OM}$ & 588.00 & 75.83 & 157.63 & 68.20 \\
\hline $\mathrm{RP}+\mathrm{OM}$ & 621.49 & 78.66 & 151.33 & 61.90 \\
\hline $\mathrm{SSP}+\mathrm{Bio}$ & 678.30 & 78.70 & 157.62 & 64.80 \\
\hline $\mathrm{RP}+\mathrm{Bio}$ & 593.65 & 75.86 & 152.42 & 63.70 \\
\hline F- test & $* *$ & $*$ & $* *$ & $*$ \\
\hline LSD \% & 54.761 & 10.603 & 7.16 & 7.53 \\
\hline
\end{tabular}

These results agree with those obtained by (Abdel-Haleem, 1994 and Abdalla, 2002) who showed the impact of phosphorus application on faba bean and noted that when increased phosphorus fertilizers viability increased vegetative growth characteristics (i.e. Plant height; fresh and dry weight and plant).

Data in Table (5) indicated that No. of seed plant 1 was significantly increased due to the addition treatments; As the data shown, the highest No of seed plant $^{-1}$ was recorded under the treatment $(\mathrm{RP}+\mathrm{Bio})$ with (83.0 plant $\left.^{-1}\right)$ with increase rate of $(52.82 \%)$ when compared with the control treatment. It noticed that (SSP) with organic fertilizers gives higher values of No. seed plant ${ }^{-1}$ than (RP) with organic fertilizers. The highest value of 100- seeds weight found owing to the treatment (SSP+ Bio) with the value (103.9) causing an increas of (35.6\%) compared with untreated soil. Data illustrated that the (SSP) with bio and organic fertilizers give higher values of seed yield than RP with bio and organic fertilizers.

Table 5. Effect of sources of phosphorus fertilizers with and without bio and organic fertilizers on number of seeds and weight of $\mathbf{1 0 0}$ seeds in faba bean

\begin{tabular}{lcc}
\hline Treatment & No. of Seeds plant & $\mathbf{1 0 0}$-seed weight \\
\hline Control & 54.31 & 76.61 \\
SSP & 74.31 & 87.31 \\
RP & 70.00 & 81.82 \\
SSP + OM & 80.10 & 97.00 \\
RP + OM & 77.00 & 92.81 \\
SSP + Bio & 80.30 & 103.9 \\
RP + Bio & 83.00 & 94.20 \\
F- test & $* *$ & $*$ \\
LSD \% & 10.2 & 14.1 \\
\hline
\end{tabular}

In this context, Kpomblekou and Tatabai, (1994) explained that organic acids dissolved more $\mathrm{P}$ by their proton supply, and showed chelation of the metals associated with $\mathrm{P}$ in the PR. Evidence of organic matter in the soil in improving the availability of PR to plants relative to $\operatorname{TSP}($ Triple super phosphate), which revealed greater dissolution of the PR. The maximum dissolution of PR in the soil, which contained the higher level of organic matter like greater cation exchange capacity and high calcium buffering capacity.

\section{Quality parameters of faba bean:}

Data in Table (6) showed the mean values of chlorophyll in leaves at flowering stage and protein in seeds as affected by organic and biofertilization during the experimental season. The data revealed a nonsignificant increase in the mean values of chlorophyll compared with the control treatment. It could be observed that the addition of (RP+ Bio) showed the highest increase in chlorophyll value (22.9 SPAD) with an increased rate $(19.9 \%)$ compared to control.

Table 6. Effect of sources of phosphorus fertilizers with and without bio and organic fertilizers on chlorophyll at flowering stage and protein in seeds

\begin{tabular}{lccc}
\hline Treatment & $\begin{array}{c}\text { Chlorophyll } \\
\text { (SPAD) }\end{array}$ & $\begin{array}{c}\text { Crude Protein } \mathbf{~ g ~ K g}^{-1} \\
\text { Straw }\end{array}$ & Seeds \\
\hline Control & 19.1 & 82.2 & 228.1 \\
SSP & 20.2 & 118.8 & 262.5 \\
RP & 21.1 & 89.7 & 258.4 \\
SSP + OM & 21.2 & 125.1 & 277.0 \\
RP + OM & 22.2 & 108.4 & 281.3 \\
SSP + Bio & 21.1 & 121.0 & 284.4 \\
RP + Bio & 22.9 & 96.9 & 275.0 \\
F- test & Ns & $* *$ & $*$ \\
LSD \% & 2.7 & 1.58 & 3.331 \\
\hline
\end{tabular}

Data also reveals a significant increase in the mean values of crude protein as affected by the treatment during the experimental season for both straw and seeds compared with the control treatment. The highest values (125.1 $\left.\mathrm{g} \mathrm{kg}^{-1}\right)$ for straw with an increase of $(52.2 \%)$ owing to the treatment of (SSP+ O.M). while, the highest value $\left(284.4 \mathrm{~g} \mathrm{~kg}^{-1}\right)$ for seed with an increase of $(24.7 \%)$ owing to the treatment of (SSP+ Bio). The obtained results stated that SSP with bio and organic at all treatment gives higher values of crude protein than RP. The data also reveal a significant increase in the mean values of crude protein as affected by the treatments in the experimental season in seeds of faba bean. The present results are in agreement with those obtained by Abou Hussien et al., (2002) who showed that using phosphorus fertilizer applications increased the percentage of seed protein.

\section{The chemical composition of faba bean at harvest} stage:

Data presented in Table (7) showed that the treatment (SSP + O.M) achieved the most increase in $\mathrm{N}$ content in the straw at harvest stage $\left(20 \mathrm{~g} \mathrm{~kg}^{-1}\right)$ at an increased rate of $(51.5 \%)$ comparing to untreated soil. While treatment (SSP) with bio and organic fertilizers give higher values of $\mathrm{N}$ than $\mathrm{RP}$ with bio and organic fertilizers. In addition, Data in the same table also illustrated the mean values of $(\mathrm{P})$ contents were high significantly increased. The treatment (SSP+ O.M) achieved the most increase in P (2.6 $\left.\mathrm{g} \mathrm{kg}^{-1}\right)$ at an increased rate of $(62.5 \%)$ comparing to untreated soil. It noticed that (SSP) with bio and organic 
fertilizers gives higher values of $(\mathrm{P})$ than $\mathrm{RP}$ with bio and organic fertilizers.

Data illustrated the mean values of $(\mathrm{K})$ contents were high significantly increased. The treatment (SSP+ Bio) achieved the most increase in $\mathrm{K}\left(35.5 \mathrm{~g} \mathrm{~kg}^{-1}\right)$ at an increased rate of $(49.8 \%)$ comparing to control treatment. It noticed that (SSP) with bio and organic fertilizers gives higher values of $(\mathrm{K})$ than RP with bio and organic fertilizers.

It could be revealed that the mean values of $\mathrm{Fe}$, $\mathrm{Zn}$, and $\mathrm{Mn}\left(\mathrm{mg} \mathrm{kg}^{-1}\right)$ were high significantly increased with the addition of bio and organic fertilization.

Table 7. Effect of sources of phosphorus fertilizers with and without bio and organic fertilizers on macronutrients (N, $P$, and $K$ ) and micronutrients ( $\mathrm{Fe}, \mathrm{Zn}$, and $\mathrm{Mn}$ )content in the straw at harvest stage in faba bean.

\begin{tabular}{lcccccc}
\hline \multirow{2}{*}{ Treatment } & \multicolumn{3}{c}{$\begin{array}{c}\text { Macro-nutrients } \\
\left(\mathbf{g ~ k g}^{-1}\right)\end{array}$} & \multicolumn{3}{c}{$\begin{array}{c}\text { Micro-nutrients } \\
(\mathbf{m g ~ k g}\end{array}$} \\
\cline { 2 - 7 } & $\mathbf{N}$ & $\mathbf{P}$ & $\mathbf{K}$ & $\mathbf{F e}$ & $\mathbf{Z n}$ & $\mathbf{M n}$ \\
\hline Control & 13.2 & 1.60 & 23.7 & 373.7 & 45.45 & 58.6 \\
SSP & 19.0 & 2.30 & 29.6 & 494.3 & 56.4 & 69.57 \\
RP & 14.4 & 2.10 & 27.6 & 428.0 & 44.1 & 67.9 \\
SSP + OM & 20.0 & 2.60 & 34.9 & 536.7 & 62.0 & 71.1 \\
RP + OM & 17.0 & 2.40 & 28.7 & 549.0 & 68.0 & 70.2 \\
SSP + Bio & 19.0 & 2.40 & 35.5 & 728.3 & 58.2 & 77.0 \\
RP + Bio & 15.5 & 2.30 & 30.0 & 608.3 & 61.5 & 75.97 \\
F- test & $* *$ & $* *$ & $* *$ & $* *$ & $* *$ & $* *$ \\
LSD \% & 0.25 & 0.02 & 0.29 & 39.75 & 6.35 & 7.38 \\
\hline
\end{tabular}

The mean values of $(\mathrm{Fe})$ contents were high significantly increased. The highest value in $\left(\mathrm{Fe} \mathrm{mg} \mathrm{kg}{ }^{-1}\right)$ was the addition of (SSP+ bio) $\left(728.3 \mathrm{mg} \mathrm{kg}^{-1}\right)$ at an increased rate of $(94.9 \%)$. As shown from the table that (SSP) with biofertilizers gives higher values of (Fe mg $\mathrm{kg}^{-1}$ ) than RP with bio and organic fertilizers. However, It noticed that (RP) with organic fertilizers gives higher values of $\left(\mathrm{Fe} \mathrm{mg} \mathrm{kg}{ }^{-1}\right)$ than SSP with organic fertilizers. The mean values of $(\mathrm{Zn})$ contents were high significantly increased. The highest value in $(\mathrm{Zn})$ was the addition of (Rp+ O.M) (68 mg kg $\left.{ }^{-1}\right)$; respectively at an increased rate of $(49.6 \%)$. It noticed that (RP) with bio and organic fertilizers gives higher values of $\mathrm{Zn}$ than SSP with bio and organic fertilizers. The mean values of $(\mathrm{Mn})$ contents were high significantly increased. The highest value in (Mn) was the addition of (SSP+ Bio) $\left(77 \mathrm{mg} \mathrm{kg}^{-1}\right)$ at an increased rate of $(31.4 \%)$. It noticed that (SSP) with bio and organic fertilizers gives higher values of (Mn) than $\mathrm{RP}$ with bio and organic fertilizers.

Data presented in Table (8) showed that the mean values of $(\mathrm{N})$ content were significantly increased. The highest increase in $(\mathrm{N})$ was in the treatment (SSP+ Bio) as $\left(45.5 \mathrm{~g} \mathrm{~kg}^{-1}\right)$ at an increased rate of $(24.7 \%)$. It noticed that (SSP) with bio and organic fertilizers gives higher values of $(\mathrm{N})$ content than RP except of (RP+ $\mathrm{OM})$ which gave a value high than $(\mathrm{SSP}+\mathrm{OM})$.

The mean values of $(\mathrm{P})$ contents were high significantly increased as affected by the treatments. The highest increase in (P) was in the treatment (SSP+ Bio) as $\left(6.9 \mathrm{~g} \mathrm{~kg}^{-1}\right)$ at an increased rate of $(43.8 \%)$. It noticed that (SSP) with bio and organic fertilizers gives higher values of (P) than RP with bio and organic fertilizers.

Table 8. Effect of sources of phosphorus fertilizers with and without Bio and organic fertilizers on $(\mathrm{N}, \mathrm{P}$, and $K)$ percentage macronutrients and micronutrients content ( $\mathrm{Fe}, \mathrm{Zn}$, and $\mathrm{Mn}$ ) of seeds of faba bean

Macronutrients Micronutrients content

\begin{tabular}{|c|c|c|c|c|c|c|}
\hline \multirow{2}{*}{ Treatmen } & \multicolumn{3}{|c|}{$\begin{array}{l}\text { Macronutrients } \\
\text { content }\left(\mathrm{g} \mathrm{kg}^{-1}\right)\end{array}$} & \multicolumn{3}{|c|}{$\begin{array}{l}\text { Micronutrients content } \\
(\mathrm{mg} \mathrm{Kg})\end{array}$} \\
\hline & $\mathbf{N}$ & $\mathbf{P}$ & K & $\begin{array}{c}\mathrm{Fe} \\
\left(\mathrm{mg} \mathrm{kg}^{-1}\right)\end{array}$ & $\begin{array}{c}\mathrm{Zn} \\
\left(\mathrm{mg} \mathrm{kg}^{-1}\right)\end{array}$ & $\begin{array}{c}\text { Mn } \\
\left(\mathrm{mg} \mathrm{kg}^{-1}\right)\end{array}$ \\
\hline Control & 36.5 & 4.8 & 8.9 & 152.40 & 26.35 & 10.50 \\
\hline SP & 42.0 & 5.8 & 9.7 & 327 & & \\
\hline $\mathrm{RP}$ & 42.0 & 5.2 & 9.0 & 345 . & 29.87 & \\
\hline $\mathrm{SSP}+\mathrm{OM}$ & 44.0 & 6.6 & 9.8 & 356.40 & 38.20 & 23.8 \\
\hline $\mathrm{P}+\mathrm{OM}$ & 45.0 & 5.8 & 9.7 & 422.50 & 37.00 & 21. \\
\hline $\mathrm{SSP}+\mathrm{Bio}$ & 45.5 & 6.9 & 9.8 & 360.70 & 36.70 & 28.57 \\
\hline $\mathrm{RP}+\mathrm{Bio}$ & 44.0 & 6.0 & 9.0 & 353.50 & 41.40 & 26.67 \\
\hline F- test & $*$ & $* *$ & $* *$ & $* *$ & $* *$ & $* *$ \\
\hline LSD $\%$ & 0.53 & 0.09 & 0.03 & 39.98 & 5.13 & 4.20 \\
\hline
\end{tabular}

The mean values of $(\mathrm{K})$ contents were high significantly increased. The highest increase in $(\mathrm{K})$ was obtained due to the treatments of (SSP+ Bio) and (SSP+ $\mathrm{OM})$ which gave the same value $\left(9.8 \mathrm{~g} \mathrm{~kg}^{-1}\right)$ causing increase of $(10.1 \%)$ over the control treatment. It noticed that (SSP) with bio and organic fertilizers gives higher values of $(\mathrm{K})$ than $\mathrm{RP}$ with bio and organic fertilizers.

The highest value $\left(\mid 422.5 \mathrm{mg} \mathrm{kg}{ }^{-1}\right)$ in $(\mathrm{Fe})$ concentration was obtained due to the addition of (RP + O.M); respectively with an increase rate of $(177 \%)$. In addition, It noticed that (SSP) with biofertilizers gives higher values of $\mathrm{Fe}(\mathrm{mg} \mathrm{kg})$ than $\mathrm{RP}$ with biofertilizers. It could be revealed that the mean values of $(\mathrm{Zn})\left(\mathrm{mg} \mathrm{kg}^{-1}\right)$ were significantly increased with phosphorus fertilizers solely or combined with bio and organic fertilization. The highest value $\left(414 \mathrm{mg} \mathrm{kg}^{-1}\right)$ in $(\mathrm{Zn})$ concentration was found due to the addition of $(\mathrm{RP}+\mathrm{Bio})$ causing an increase rate of $(57.1 \%)$ over the untreated plants. It noticed that (SSP) with organic fertilizer gives higher value of $(\mathrm{Zn})$ content than RP with organic fertilizers. As for $\mathrm{Mn}$ content, data revealed that the mean values of $(\mathrm{Mn})$ were significantly increased with the addition of treatments. The highest value $\left(28.57 \mathrm{mg} \mathrm{kg}^{-1}\right)$ of $(\mathrm{Mn})$ concentration was observed owing to the addition of (SSP+ Bio) with an increase rate of $(172 \%)$ compared to the control treatment. It noticed that (SSP) with bio and organic fertilizers gives higher values of $(\mathrm{Mn})$ than RP with bio and organic fertilizers. The present results are in agreement with those obtained by Hellal et al., (2013) who showed that adding compost to RP improve the efficient use of RP, and these significantly increased the values of weight of grains plant ${ }^{-1}, 100$-grain weight and grains yields. While, treatment RP + compost achieved the greatest one for 100-grain weight and significantly increased uptake (N, P, K) as well as (Fe, Mn, Zn).

Data illustrated that the mean values of available $\mathrm{N}, \mathrm{P}$ and $\mathrm{K}$ in soil after faba bean harvest were high significantly increased effected by the treatment .The treatment of (SSP+OM) was supenion to the other treatments and give the highest values (102.6, 8.3 and 
268.4), respectively. El-Ghamry et al., (2015) reported that organic manure is one of the sources of nitrogen in the soil. Nitrogen mineralization depends on application method, the source of organic manure, microbial activity, aeration, and moisture. Nitrogen mineralization is the process by which organic $\mathrm{N}$ is converted to inorganic forms which mostly ammonium $\left(\mathrm{NH}_{4}{ }^{+}\right)$and nitrate $\left(\mathrm{NO}_{3}{ }^{-}\right)$. When manures are regularly added to soils, the mineralization gradually increases over time until it eventually reached a plateau known as the steady-state condition

Table 9. Some chemical analysis of soil after harvest

\begin{tabular}{lccc}
\hline \multirow{2}{*}{ Treatment } & \multicolumn{3}{c}{ Available Macronutrient in soil $\left(\mathbf{m g ~ k g}^{-1}\right)$} \\
\cline { 2 - 4 } & $\mathbf{N}$ & $\mathbf{P}$ & $\mathbf{K}$ \\
\hline Control & 84.31 & 4.99 & 222.24 \\
SSP & 86.67 & 6.83 & 227.95 \\
RP & 86.00 & 5.42 & 246.75 \\
SSP + OM & 102.60 & 8.30 & 268.40 \\
RP + OM & 91.80 & 6.38 & 252.77 \\
SSP + Bio & 101.00 & 7.15 & 249.38 \\
RP + Bio & 97.00 & 5.85 & 265.29 \\
F-test & $* *$ & $* *$ & $*$ \\
LSD \% & 9.95 & 1.37 & 28.59 \\
\hline
\end{tabular}

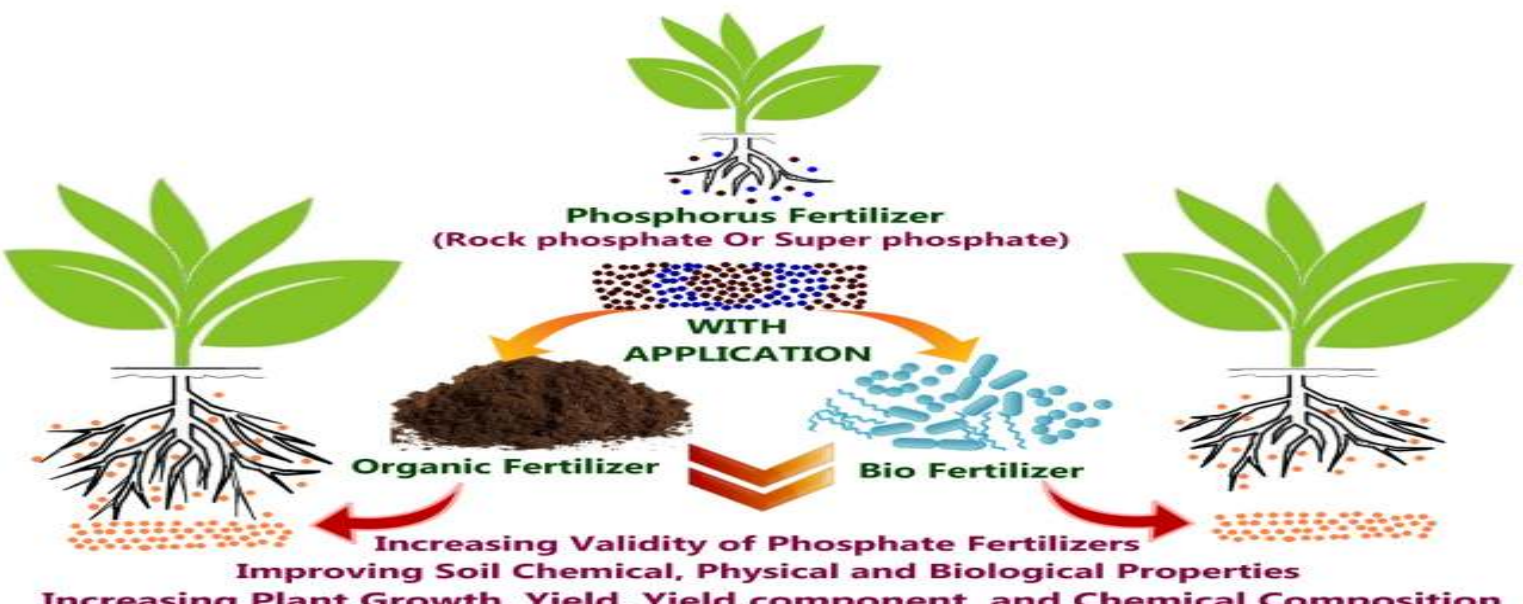

Increasing Plant Growth, Yield, Yield component and Chemical Composition

Fig. 1. Effect of sources of phosphorus fertilizers with and without bio or organic fertilizers on the beans cultivated in clay soil

\section{CONCLUSION}

From the results mentioned previously and as shown from Fig (1) it could be concluded that: growth parameters, yield and yield components and chemical composition of the faba bean plant were greatly increased as a result of treating rock or superphosphate with biofertilization and organic fertilizers. Biofertilization increases the availability of phosphorus in rock phosphate in the studied clay soil, where $\mathrm{P}$ is fixed due to high $\mathrm{pH}$. Accordingly; under the same conditions of this investigation it could be recommended that; using organic and biofertilizers coupled with rock or superphosphate increase the availability of plant nutrients, production and reduces the soil pollution resulted from mineral fertilizers as shown in the figure which explains the impact of using organic and biofertilizers with rock or superphosphate increase the efficiency or validity of them, Therefore, improving the soil chemicals, physicals, and biological properties and increasing plant growth, yield, yield component, and chemical competition

\section{REFERENCES}

Abdalla, A. M. (2002). Effect of bio- and mineral phosphorus fertilizer on the growth, productivity and nutritional value of faba bean. Egypt. J. Hort., 29 (2): 187-203.

Abdel-Haleem, A. K. (1994). Growth and yield of faba bean as affected by inoculation, phosphorus fertilization and irrigation frequency. J. Agric. Sci. Mans. Univ., 19 (11): 3563-3574.
Abou El-Yazeid, A. and Abou-Aly, H. E. (2011). Enhancing growth, productivity, and quality of tomato plants using phosphate-solubilizing microorganisms. Australian Journal of Basic and Applied Sciences, 5(7): 371- 379.

Abou Hussien, E. A.; Abou El-Fadl, M. A.; Radwan, S. A. and Khalil, H. M. (2002). Response of wheat and broad bean plants to phosphorus under different soil conditions. Egypt J. Agric. Res., 80 (1): 41-55.

Aggelides, S. M. and Londra, P. A. (2000). Effect of compost produced form town wastes and sewage sludge on the physical proportion of a loamy and clay soils Bio. Technol., (71): 253-259.

AOAC (1970). "Association of Official Agriculture Chemistis". Methods of Analysis, 11th Edition, Washington, D.C.

Baddour, G. A.; El-Ghamry, A. M. and El-Hammady, M. M. (2004). Zinc status in snap bean plant (Phaseolus vulgaries 1.) as affected by phosphorus fertilization with or without phosphate dissolving bacteria. Microbiology and Biotechnology in Favour of Man and Environment in Africa and Arab Region, Mansoura University (27-29 April. 2004) 443-474.

Biswas, D. R. and Narayanasamy, G. (2002). Mobilization of phosphorus from rock phosphate through composting using crop residue. Fert News 47:53-56. 
Black, C. A; Evans, D. D.; White, I. I.; Ensminger, L. E. and Clark, F. E. (1965). "Methods of soil analysis". Amer. Soc. Agron. Inc., Ser. 9 in Agron., Madison, Wisconsin.

Brady, N. C. (1990). The nature and properties of soils. $10^{\text {th }}$ Ed., Machmillan Publishing Company. New York.

Chapman, H. D. and Pratt, P. F. (1961). Methods of Analysis for Soils, Plants and Waters. Soil Science, 93(1), 68.

Chaturvedi, S; Uoreti, D. K.; Tandon, D. K.; Sharma, A. and Dixit, A. (2008). Bio-waste from tobacco industry as tailored organic fertilizer for improving yields and nutritional values of tomato crop. J. Environ. Bio. (29):759-763.

Duc, G. (1997). Faba bean (Vicia faba L.). Field Crops Research, 53(1-3), 99-109.

Elgala, A. M., and Amberger, A. (2017). Factors Affecting Solubilization of Rock Phosphates in Soils. International Journal of Plant \& Soil Science 14(1): $1-8$.

El-Ghamry, A. M.; Abd El-Hai, K. M. and Ghoneem, Kh. M. (2009). Amino and Humic Acids Promote Growth, Yield and Disease Resistance of Faba Bean Cultivated in Clayey Soil. Australian J. Basic and Applied Sciences, 3(2): 731-739.

El-Ghamry, A. M.; Ghazi, D. A. M. and Amaref, M. A. A. (2015). Effect of organic manures application on $\mathrm{N}$ mineralization at different Egyptian soils. Soil Sci. and Agric. Eng., Mansoura Univ., 6 (11): $1327-$ 1339.

El-Ghamry, A. M.; Mosa, A. A. and El-Sayed, K. M. (2016) .Toward a new generation of organic manures: enriched-compressed organic manure as a substitution of ordinary compost in organic farming systems. Soil Sci. and Agric. Eng., Mansoura Univ., 7 (4): $317-324$

El-Ghandour, A.; El-Sharawy, A. O. and Abdel-Moniem, E. M. (2005). Impact of vesicular arbuscular mycorrhizal fungi and Rhizobium on the growth and $\mathrm{P}, \mathrm{N}$ and Fe uptake by faba-bean. Research J. Agric. and Biological Sci., 43(1):43-48.

Escobar, M. E. and Hue, N. V. (2008).Temporal changes of selected chemical properties in three manure amended soils of Hawaii. Bio-resource Tech., 99; 8649-8654.

Finck, A. (1982). Fertilizers and Fertilization. Weinheim Deerfield Beach, Florida, Basel, Verlage Chemie, pp. 223.

Ghani, A.; Rajan, S. and Lee, A. (1994). Enhancement of rock phosphate solubility through biological processes. Soil Biol Biochem 26:127-136.

Glæsner, N.; Bælum, J.; Jacobsen, C. S.; Ritz, C.; Rubæk, G. H.; Kjaergaard, C. and Magid, J. (2016). Bacteria as transporters of phosphorus through soil. European Journal of Soil Science, 67(1); 99-108.

Goldstein, A. H.; Baertlein, D. A. and McDaniel, R. G. (1998). Phosphate starvation inducible metabolism in Lycopersicon esculentum. Plant Physiology, 87: 711-715.

Gomez, K.A. and Gomez, A. A. (1984). "Statistical Procedures for Agricultureal Research". $2^{\text {nd }}$ ed. John Wiley and Sons, pp: 229-308.
Haile, D.; Mekbib, F. and Assefa, F. (2014). Evaluation the Efficiency of Phosphate Solubilizing Bacterial Isolates. International Journal of Emerging Technology and Advanced Engineering, 4(1); 774 783.

Hellal, F. A. A.; Nagumo, F. and Zewainy, R. M. (2013). Influence of phosphocompost application on phosphorus availability and uptake by maize grown in red soil of Ishigaki Island, Japan. Agric., Sci. 4(02), 102.

Hesse, P. R. (1971). "A Text Book of Soil Chemical Analysis". John Murry (Publishers) Ltd., 50 Albermarle Street, London.

Iyamuremye, F and Dick, RP. (1996) Organic amendments and phosphorus sorption by soils. Adv Agron 56:139-185.

Jackson, M. L. (1967). "Soil Chemical Analysis". PrinticeHall of India, New Delhi.

Johnston, A. (2001). Phosphorus Fertilization - Sources and Efficiency. Regional Newsletter, Potash \& Phosphate Institute (PPI) and Potash \& Phosphate Institute of Canada (PPIC).

Khan, M. S.; Zaidi, A. and Ahmad, E. (2014). Mechanism of phosphate solubilization and physiological functions of phosphate-solubilizing microorganisms. In Phosphate Solubilizing Microorganisms (pp. 31-62). Springer International Publishing.

Kpomblekou, K. and Tatabai, M. A. (1994). Effect of organic acids on release of phosphorus from phosphate rocks. J. Soil Sci., 158: 442-453.

Mathieu, c. and pieltain, F. (2003). Chemical Soil Analysis: chosen methods.pp.388.

Mosa, A. A. (2012). Effect of humic substances application on potato tubers yield quantity, quality, nutrients concentration under Egyptian soil conditions. In: Zhongqi, H. Robert, L., Wayne, H. (eds.). Sustainable Potato Production: Global Case Studies. Springer. Amesterdam. The Netherlands.

Muraleedharan, H.; Seshadri, S. and Perumal, K. (2010) "Biofertilizers (Phospho Bacteria)".Shri AMM Murugappa Chettiar Research Center (MCRC).

Nassib, A. M.; Khalil, S. A. and Hussein, A. H. A. (1991). Faba bean production and consumption in Egypt. Ciheam Options Mediterraneannes, 10: 127-131.

Olsen, S. R. and Sommers, L. F. (1982). "Methods of Soil Analysis. Part 2. Chemical and microbiological Properties. Agron. J. Amer. Soc. Agron. Madison, Wiss, USA: 403-430

Peterburgski, A. V. (1968). "Handbook of Agronomic Chemistry". Kolop Publishing House, Moscow, Russia.

Piper, C. S. (1950). "Soil and Plant Analysis", Inter. Science, Publisher. Inc. NewYork.

Rai, M.K., (2006). " Handbook of Microbial Biofertilizers". Food Products Press, an imprint of The Haworth Press, Inc, Binghamton, New York

Richards, L. A. (1954). "Diagnosis and Improvement of Saline and Alkali Soils".USDA, Handbook, 60.

Rodriguez, H. and Fraga, R. (1999). Phosphate solubilizing bacteria and their role in plant growth promotion. Biotechnol Adv. 17:319-339. 
Singh, CP. and Amberger, A. (1991). Solubilization and availability of $\mathrm{P}$ during decomposition of rock phosphate enriched straw and urine. Biol. Agric. Hortic., 7:261-269.

Singh, CP. and Amberger, A. (1995). The effect of rock phosphate enriched compost on the yield and phosphorus nutrition of rye grass. Am. J. Altern. Agric., 10:82-87.

Singh, CP. and Amberger, A. (1998). Organic acids and phosphorus solubilization in straw composted with rock phosphate. Bioresour. Technol., 63:13-16.

Steel, R. G. D. and Torrie, J. H. (1980). Principles and Procedures of Statistics. 2nd ed. Mc Graw Hill International Book Company, New York, USA..
Van Kauwenbergh, S. J. (2010). World phosphate rock reserves and resources (p. 48). Muscle Shoals: IFDC.

Vassilev, N.; Vassileva, M.; Medina, A. and Azcon, R. (2002). Fungal solubilization of rock phosphate on media containing agro-industrial wastes. In: Proceedings of Microbial phosphate solubilization. Salamanca, Spain, p 37, http://webcd.usal.es/psm.

Whitelaw, MA. (2000). Growth promotion of plants inoculated with phosphate-solubilizing fungi. Adv Agron 69:99-151.

Wong, M. T. F. and Swift, R. S. (2003). Role of Organic Matter in Alleviating Soil Acidity. In: Rengel, Z., Ed., Handbook of Soil Acidity, Marcel Dekker, Inc., New York, 337-358. Yields and nutritional values of tomato crop. J. Environ. Bio., (29):759-763.

\section{دور الأسمدة العضوية والحيوية في صلاحية الأسمدة الفوسفاتية وتأثير ها على الفول النامي في تربة طينية

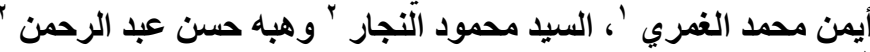

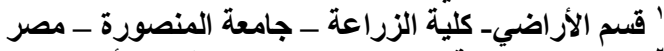

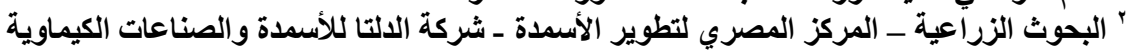

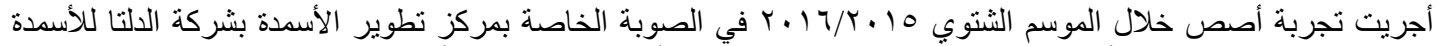

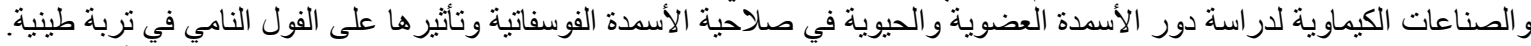

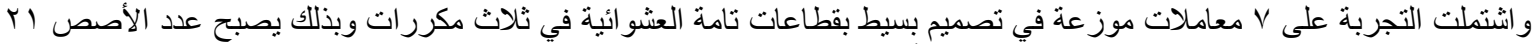

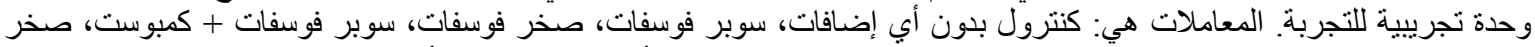

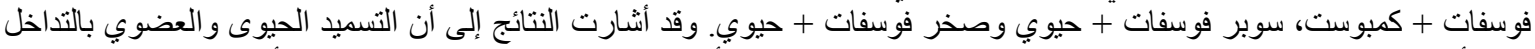

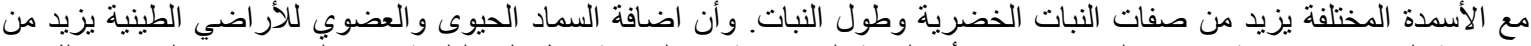

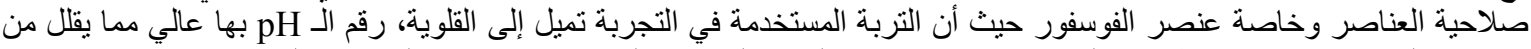

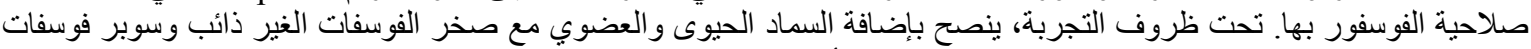
لزيادة معدل امتصاص عنصر الفوسفور وبقية العناصر، كما أنه يزيد من انتاجية المحصول ويقال ويقلل تلوث التربة الناتج عن إضافة التسميد 